
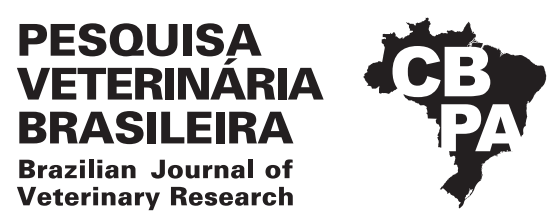

Pesq. Vet. Bras. 38(8):1564-1569, agosto 2018 DOI: 10.1590/1678-5150-PVB-5521

Original Article

ISSN 0100-736X (Print)

ISSN 1678-5150 (Online)

\title{
Efficacy of faecal microbiota transplantation for treating acute colitis in horses undergoing colic surgery ${ }^{1}$
}

\author{
Deborah P.M. Dias ${ }^{2 *}$, Samuel S. Sousa², Flávia A. Molezini² ${ }^{2}$ Henrique S.D. Ferreira² \\ and Reinaldo de Campos $^{3}$
}

\begin{abstract}
Dias D.P.M., Sousa S.S., Molezini F.A., Ferreira H.S.D. \& Campos R. 2018. Efficacy of faecal microbiota transplantation for treating acute colitis in horses undergoing colic surgery. Pesquisa Veterinária Brasileira 38(8):1564-1569. Centro Universitário Barão de Mauá, Av. Patriarca 4700, Ribeirão Preto, SP 14031-580, Brazil. E-mail: deborah_dias@hotmail.com

The report describes the outcome of four horses treated with homologous faecal microbiota transplantation (FMT) for acute colitis. The horses developed diarrhoea and fever a few days after a laparotomy to treat gastrointestinal disease. Medical records were reviewed to identify the horses as well as to describe the primary intestinal disease, clinical findings, surgical intervention, FMT protocol, outcome and follow-up of each case. The principle of the efficacy of FMT is that restoration of a balanced nonpathogenic bacterial population may be the primary defence mechanism against colonization of pathogenic bacteria in the equine gastrointestinal tract. The FMT did not produce adverse reactions and was demonstrated to rapidly control diarrhoea and fever in all cases. A complete resolution of clinical sings was observed within 24 hours when horses were given a single FMT. Further clinical studies are necessary to determine the optimal preparation and to reinforce the efficacy of FMT for treating acute colitis following colic surgery. The technique has the potential to be an inexpensive, safe and highly efficient tool for the prevention and treatment of infectious gastrointestinal diseases in horses, preventing antimicrobial resistance.
\end{abstract}

INDEX TERMS: Microbiota transplantation, treatment, colitis, horses, bacteriotherapy, diarrohea, intestinal microbiota, surgery.

\begin{abstract}
RESUMO.- [Eficácia do transplante de microbiota fecal no tratamento da colite aguda em equinos submetidos a cirurgia de cólica.] 0 presente relato descreve a recuperação de 4 equinos tratados com transplante homólogo de microbiota fecal (TMF) para colite aguda. Os animais desenvolveram diarreia e febre alguns dias após serem submetidos a laparotomia para tratar obstruções intestinais. Os registros médicos foram revisados para identificar os equinos, bem como para descrever a doença intestinal primária, achados clínicos, detalhes da intervenção cirúrgica, protocolo do TMF, resultados e evolução de cada caso. 0 princípio da eficácia

\footnotetext{
${ }^{1}$ Received on January 3, 2018.

Accepted for publication on January 16, 2018.

${ }^{2}$ Centro Universitário Barão de Mauá, Av. Patriarca 4700, Ribeirão Preto, SP 14031-580, Brazil. *Corresponding author: deborah_dias@hotmail.com

${ }^{3}$ Equine Center, Jockey Club de São Paulo, Rua Bento Frias 248, Grupo 39, São Paulo, SP 05423-050, Brazil.
}

do TMF é que a restauração do equilíbrio de bactérias não patogênicas pode ser o principal mecanismo de defesa contra a colonização por bactérias patogênicas no trato gastrointestinal equino. 0 TMF não ocasionou reações adversas e demonstrou controlar rapidamente a diarreia e a febre em todos os casos. A resolução completa dos sinais clínicos foi observada dentro de 24 horas, sendo que os cavalos receberam um único TMF. Estudos clínicos adicionais são necessários para determinar a melhor técnica de preparação e para reforçar a eficácia do TMF no tratamento da colite aguda após cirurgia de cólica. A técnica tem potencial para ser uma ferramenta de baixo custo, segura e altamente eficiente para a prevenção e tratamento de doenças infecciosas gastrointestinais em equinos, evitando a resistência antimicrobiana.

TERMOS DE INDEXAÇÃO: Microbiota, tratamento, colite, equinos, bacterioterapia, diarreia, microbiota intestinal, cirurgia. 


\section{INTRODUCTION}

Enteritis and colitis are inflammatory diseases of the equine gastrointestinal tract (GIT) associated with high morbidity and mortality in adult horses (Feary \& Hassel 2006). The term 'acute equine colitis' refers to the involvement of the caecum (typhlitis) and/or colon (colitis) of the adult horse. Disease onset is sudden and often preceded by a stressful event, and if untreated, $90 \%$ of horses die or are euthanized due to rapid and severe debilitation (McConnico 2009). The disease may result from an infectious aetiology, such as salmonellosis, clostridiosis, Potomac horse fever (Neorickettsia risticii) or strongyle infestation, or the cause may be a non-infectious one, such as carbohydrate overload, antimicrobial administration, ulcerative colitis from nonsteroidal anti-inflammatory drug (NSAID) toxicity, arsenic poisoning, cantharidin (blister beetle) toxicosis, peritonitis, sand enteropathy or inflammatory bowel disease (Feary \& Hassel 2006, McConnico 2009).

Regardless of the aetiology, acute colitis in horses is characterized by high fever and severe watery diarrhoea, which occurs in response to intraluminal sequestration of fluid. The acute fluid loss is a result of intestinal epithelium lesions, which cause malabsorptive and hypersecretory processes in combination. Epithelial injury, such as ulceration and erosion, also allows transmural migration of endotoxins (McConnico 2009). Due to the large amount of bacterial proliferation and the subsequent release of endotoxins upon their death, horses with acute colitis often experience severe sepsis, showing signs such as depression, lethargy, tachycardia, tachypnea, congested mucous membranes with or without a toxic ring, prolonged capillary refill time, injected sclera, weak peripheral pulses and cold extremities (Roy 2004). Abdominal discomfort may occur due to intestinal distention by sequestered fluid or due to the high amount of gas produced by uncontrolled bacterial fermentation (Southwood 2006). Hypermotility always causes pain, but the horse may also present dysmotility or ileus, accompanied by partial or complete anorexia (Magdesian 2003).

The challenge of diagnosis is to determine the affected intestinal segment and the most important pathogen associated with the disease. Information on history, clinical signs, laboratory exams and ultrasound examination could be enlightening, although in some cases definite diagnosis is confirmed only upon laparotomy or necropsy (DuToit et al. 2010). Several methods are currently available to identify the aetiologic agent, but ELISA tests are the most commonly used (Uzal \& Diab 2015).

Treatment includes nutritional support, control of enteric inflammation with NSAIDs; adequate replenishment of fluids, electrolytes and colloids; reduction of fluid secretion; control of endotoxaemia and sepsis; and re-establishment of normal flora (Feary \& Hassel 2006, Hackett \& Hassel 2009). Antimicrobial medication is indicated but controversial, since it can destroy commensal flora and favour proliferation of enteric pathogens, aggravating the disease (Feary \& Hassel 2006). Thus, the treatment of colitis essentially involves the improvement of the general condition of the horse and the balance of intestinal flora, emphasizing the importance of microbiota optimizers.

Probiotics were initially defined in 1908 by Metchnikoff as living microorganisms ingested in food that, if present in the gastrointestinal tract in adequate quantities, can modify the flora and replace the harmful microorganisms with ones that have beneficial effects on the host's health (Metchnikoff 1908). Therefore, the organisms must pass alive through acid and bile environments, adhere to intestinal epithelial cells, colonize the intestinal tract, produce an antimicrobial factor, and inhibit enteric pathogens. Other properties include immunomodulation, modulation of metabolic activities and inactivation of procarcinogens (Gibson \& Fuller 2000, Saarela et al. 2000, Weese et al. 2004).

The effects of probiotics on the equine GIT comprise an improvement in digestive function by improving nutrient utilization and elimination of pathogenic strains by competition for substrates and epithelial adherence sites. In addition, probiotic supplementation increases the production of short-chain fatty acids within the intestine, stimulating water reabsorption even in horses with diarrhoea and supplying energy to colonocytes, which decreases colon motility. Thus, it is suggested that the use of probiotics can prevent and treat conditions that alter GIT microbiota and intestinal transit in horses. Despite the benefits, there is a constant concern about the production and administration of probiotics to horses due to the risks of transfer of antimicrobial resistance to the host's original microbiota, formation of biogenic amines and activation of carcinogenic substances. Thus, each country regulates commercial products such that they must be safe for animals, humans and the environment (Julliand \& Zeyner 2009).

Another option to balance the intestinal flora in a pathologic condition is transfaunation, or faecal microbiota transplantation (FMT). The technique consists of administering faeces samples from healthy individuals via a nasogastric tube, and its effectiveness has been demonstrated in humans for the prevention and control of Clostridium difficile-associated diarrhoea (Aas et al. 2003, Dendukuri et al. 2005, Brandt \& Reddy 2011, Brandt 2012, Ott et al. 2017). The first faecal transplantation in humans was performed in 1958. To date, approximately 450 cases of FMT for treatment of Clostridium difficile infection in humans have been reported worldwide (Brandt 2012). In veterinary medicine, rumen transfaunation is commonly used to treat GIT disorders in cattle (De Peters \& George 2014). However, there are only anecdotal reports from equine practitioners on the application of FMT from healthy horses as a successful therapy for acute and chronic diarrhoea (Feary \& Hassel 2006, Mullen et al. 2016). Considering the lack of information on the subject, the purpose of this study is to report on the clinical application of FMT to treat acute colitis in horses following colic surgery.

\section{MATERIALS AND METHODS}

Inclusion criteria. All horses diagnosed with acute colitis following colic surgery at the Veterinary Teaching Hospital between November 2015 and November 2016 were included in the study. The diagnosis of colitis was based on clinical signs during hospitalization, and the medical record of each horse was reviewed to obtain information about its gender, breed, age and weight; duration of colic prior to surgery; primary GIT disease; colitis onset and clinical findings; FMT procedure; colitis resolution and discharge status. Owners were contacted by telephone for post-discharge follow-up 6 to 18 months later.

History and surgery. The 4 horses included in the study were admitted to the Veterinary Teaching Hospital for exploratory 
laparotomy recommended by referral veterinarians. All horses received fluids, analgesics and sedatives before referral and presented with severe signs of abdominal pain. The duration of medical treatment before surgery and clinical findings on admission are described in Table 1. After the need for exploratory laparotomy was confirmed and informed consent from the owner was received, all horses were implanted with a catheter in the jugular vein and were given potassium penicillin 20,000IU/kg IV and amikacin $20 \mathrm{mg} / \mathrm{kg}$ IV. The same anaesthesia protocol was carried out for all horses, and surgery was performed in dorsal recumbency. The horses were sedated with xylazine hydrochloride $0.5 \mathrm{mg} / \mathrm{kg}$ IV and diazepam $0.1 \mathrm{mg} / \mathrm{kg} \mathrm{IV}$, after which general anaesthesia was induced with ketamine hydrochloride $2 \mathrm{mg} / \mathrm{kg}$ IV and maintained with isoflurane vaporised in oxygen in a semi-closed system. During surgery, all horses were administered with lactated Ringer's solution, lidocaine hydrochloride solution in $0.9 \%$ saline $1.3 \mathrm{mg} / \mathrm{kg}$ IV in a bolus followed by $0.05 \mathrm{mg} / \mathrm{kg} / \mathrm{min} \mathrm{IV}$, and dobutamine solution in $0.9 \%$ saline $2-5 \mathrm{mcg} / \mathrm{kg} / \mathrm{min}$ IV according to arterial pressure deficits.

Horse 1 had caecal impaction that was severely distended and heavy, with a friable and oedematous wall. Due to the risk of rupture during manipulation, rendering impossible the adequate exteriorization of the caecum apex to perform typhlotomy and lavage, risking rupture during manipulation, 5 litres of $0.9 \%$ saline containing $85.5 \mathrm{~g}$ of magnesium hydroxide was infused into the caecum. The caecal contents were then massaged, completely dissolving the impaction. Horse 2 had a 360-degree large colon volvulus; after repositioning, a $10 \mathrm{~cm}$ pelvic flexure enterotomy was performed, and the contents were drained by lavage. The large colon wall was oedematous, and the mucosal surface showed a dark red colour. Enterorrhaphy was performed in 2 layers, a full-thickness Schmieden and a seromuscular Cushing, using 0 polyglactin 910 sutures.

Horse 3 had a severe caecal impaction showing a haemorrhagic serosal surface and an oedematous wall. The caecum apex was exteriorized, a $10 \mathrm{~cm}$ longitudinal incision was performed between the lateral and ventral bands, and the contents were drained by lavage. Caecum enterorrhaphy was performed in 2 layers, a full-thickness Schmieden and a seromuscular Cushing, using 0 polyglactin 910 sutures. Horse 4 had a large faecalith obstructing the small colon and another 4 smaller faecaliths immediately oral to the large one. A $15 \mathrm{~cm}$ longitudinal enterotomy was performed on the antimesenteric band at the obstruction site, and all faecaliths were carefully pushed and removed through the same incision. Enterorrhaphy was performed in 2 layers, including a full-thickness simple-continuous pattern followed by a seromuscular Cushing, both using 0 polyglactin 910 sutures. For horses 2, 3 and 4, a $0.84 \%$ neomycin sulfate solution in $0.9 \%$ saline was used to profusely rinse the enterotomy site when each suture layer was completed.

The other findings during exploratory laparotomy were unremarkable for all horses. Prior to closure of the abdominal incision, $3 \mathrm{~L}$ of $10 \%$ DMSO solution in $0.9 \%$ saline was instilled into the peritoneal cavity. Abdominal wall synthesis was performed routinely in 3 layers. The wound was cleaned with $0.2 \%$ chlorhexidine followed by tincture of benzoin, and a microporous tape was placed over the suture line and removed after the horses recovered from anaesthesia.

Postoperative treatment and acute colitis development. All horses received fluid therapy as needed as well as the following postoperative treatments: potassium penicillin 22,000 IU/kg IV q6h for 7 days; amikacin 20mg/kg IV q24h for 5 days; metronidazole $15 \mathrm{mg} / \mathrm{kg}$ IV q12h for 3 days; flunixin meglumine $1.1 \mathrm{mg} / \mathrm{kg} \mathrm{IV} \mathrm{q12h}$ initially for 1 day, then $0.55 \mathrm{mg} / \mathrm{kg} \mathrm{IV}$, q12h for 5 days; DMSO in decreasing doses of $0.6 \mathrm{~g} / \mathrm{kg}, 0.4 \mathrm{~g} / \mathrm{kg}$ and $0.2 \mathrm{~g} / \mathrm{kg}$ in a $5 \%$ lactated Ringer's solution IV q24h for 3 days; ranitidine $1 \mathrm{mg} / \mathrm{kg}$ IV q12h for 3 days and omeprazole $4 \mathrm{mg} / \mathrm{kg}$ PO q24h from surgery until discharge. The celiotomy incision was cleaned daily with $0.2 \%$ chlorhexidine and tincture of benzoin, and a microporous adhesive tape was applied, covering the suture line.

Profuse watery diarrhoea and fever (median rectal temperature of $39.8^{\circ} \mathrm{C}$ ) were observed from 1 to 3 days after the surgical procedure. At this time, horses also showed other changes in clinical parameters, such as a median heart rate of 54 beats/min, a median respiratory rate of 26 breaths/min and oral mucous membranes revealing

Table 1. Identification and clinical findings upon admission of colic horses referred for laparotomy

\begin{tabular}{|c|c|c|c|c|}
\hline & Horse 1 & Horse 2 & Horse 3 & Horse 4 \\
\hline Gender & Mare & Stallion & Stallion & Mare \\
\hline Breed & Quarter Horse & Brazilian Sport Horse & Brazilian Sport Horse & Mixed breed \\
\hline Age & 6-year-old & 3-year-old & 5-year-old & 10-year-old \\
\hline Weight & $450 \mathrm{Kg}$ & $510 \mathrm{Kg}$ & $513 \mathrm{Kg}$ & $380 \mathrm{Kg}$ \\
\hline Activity & Three barrel racing & Show jumping & Show jumping & Reproduction \\
\hline Duration of colic prior to surgery & 1 day & 6 hours & 6 days & 3 days \\
\hline Abdominal pain & Moderate & Severe & Moderate & Moderate \\
\hline Behavior & Excited & Excited & Apathetic/Anorexic & Apathetic/Hyporexic \\
\hline Heart rate & 50 beats/min & 60 beats $/ \mathrm{min}$ & 30 beats $/ \mathrm{min}$ & 100 beats $/ \mathrm{min}$ \\
\hline Respiratory rate & 18 breaths/min & 42 breaths $/ \mathrm{min}$ & 10 breaths/min & 20 breaths $/ \mathrm{min}$ \\
\hline Oral mucous membrane & Rose and slightly dry & Congest & Slightly icteric and dry & Congest and dry \\
\hline Capillary refill time & 3 seconds & 4 seconds & 3 seconds & 5 seconds \\
\hline Intestinal auscultation & Hypomotility & Normal & Hypomotility & Atony \\
\hline Rectal temperature & $37.9^{\circ} \mathrm{C}$ & $38.1^{\circ} \mathrm{C}$ & $37.8^{\circ} \mathrm{C}$ & $37.5^{\circ} \mathrm{C}$ \\
\hline Extremities temperature & Normal & Normal & Decreased & Decreased \\
\hline Thoracic and pelvic digital pulse & Absent & Absent & Absent & Absent \\
\hline Nasogastric intubation results & Fermented intake & Hay & Nothing & Fermented intake \\
\hline Rectal palpation results & Caecal impaction & Large colon distension & $\begin{array}{l}\text { Caecal impaction and small } \\
\text { intestine distension }\end{array}$ & $\begin{array}{l}\text { Severe generalized } \\
\text { intestinal distension }\end{array}$ \\
\hline
\end{tabular}


hypoperfusion. Furthermore, hypoproteinaemia, hyperfibrinogenaemia and leukopenia were observed, and all horses presented secondary complications after colitis, such as laminitis, jugular thrombophlebitis, cachexia, peritonitis or suture line infection (Table 2). Upon acute colitis onset, horse 1 had been initially treated with sodium dipyrone $25 \mathrm{mg} / \mathrm{kg}$ IV to control fever when its rectal temperature was up to $39^{\circ} \mathrm{C}$, the prescribed postoperative medication added to fluids and plasma infusion to remediate deficits identified according to packed cell volume and total plasma protein counts. The other 3 horses were also administered sodium dipyrone $25 \mathrm{mg} / \mathrm{kg}$ IV to control fever when their temperature was up to $39^{\circ} \mathrm{C}$, and the remainder of postoperative medication was maintained as planned.

Faecal microbiota transplantation. The FMT was performed immediately upon identification of acute colitis signs for 3 horses, whereas for horse 1, FMT was performed 5 days after, when postoperative antimicrobial treatment was finished. The donor horse was considered healthy based on physical examination, had no history of infectious disease or antimicrobial therapy in the last six months, and was up to date on its vaccinations and deworming. Fresh faeces were obtained via rectal evacuation (1.5-2.0 kg) using a plastic glove lubricated with carboxymethylcellulose. The faeces were placed into a bucket, mixed with $4 \mathrm{~L}$ of fresh water and strained by compression using a cotton fabric until all liquid was drained (approximately $4.5 \mathrm{~L}$ ). Then, $40 \mathrm{~g}$ of sodium bicarbonate was added and mixed into the obtained 'faecal tea', which was immediately transferred to the horse presenting acute colitis via a nasogastric tube. The procedure was performed once for each horse, and symptoms were controlled within 24 hours; normal defecation was restored in 1 to 8 days. Table 2 summarizes the results obtained with FMT.

Complications and follow-up. Horse 1, who received FMT 5 days after diarrhoea onset, showed forelimb laminitis and jugular thrombophlebitis 3 and 6 days, respectively, after acute colitis onset. The laminitis pain was controlled with phenylbutazone $2.2 \mathrm{mg} / \mathrm{kg}$ IV q12h and abaxial sesamoid nerve blocks using bupivacaine hydrochloride $0.5 \%$. The feet were immersed in iced water to prevent lesion evolution until bounding digital pulses were present. Radiographic examination was performed following distal phalanx rotation, and once the site was stabilized, a closed horseshoe was applied. Thrombophlebitis was managed with immediate jugular catheter withdrawal, hot packs and hydrotherapy applied over the swollen vein, followed by local massages with a gel containing aescin $1 \%$ and diethylammonium salicylate $5 \%$. This procedure was carried out 4 times daily. The lateral thoracic vein was cannulated as an option for drug administration and venous blood collection. This mare was discharged with chronic laminitis support care instructions, and no diarrhoea history was reported at long-term follow-up (18 months).

Despite postoperative treatment, normal eating and oral nutritional supplementation, horse 2 developed peritonitis and cachexia and died 46 days after acute colitis onset. Nutritional parenteral support was not performed because of financial limitations. Horse 3 did not show secondary complications, and horse 4 showed a superficial wound infection 11 days after surgery. The suture was removed, and the infection resolved with povidone-iodine solution dressing followed by oxytetracycline topical spray. Both horses were discharged in 2 weeks, and no recurrence of symptoms was reported by follow-up telephone contact at 6 and 2 months after discharge. These horses regained their normal weight, and horse 3 resumed the same exercise activity as previous to hospitalization. Complications and follow-up are displayed in Table 2.

\section{DISCUSSION AND CONCLUSION}

To the authors' knowledge, this is the first clinical report that describes the use of faecal microbiota transplantation (FMT) to treat acute colitis in horses that have undergone colic surgery. The age group included in this study ( 3 to 10 years old) was in accordance with McConnico (2009), who reported that

Table 2. Gastrointestinal primary disease, clinical and laboratorial findings at diarrhoea onset, and results of faecal microbiota transplantation (FMT) in horses treated for acute colitis following colic surgery

\begin{tabular}{|c|c|c|c|c|}
\hline & Horse 1 & Horse 2 & Horse 3 & Horse 4 \\
\hline Surgical lesion & Caecal impaction & Large colon volvulus & Caecal impaction & Small colon faecaliths \\
\hline Enterotomy/Site & No & Yes/Large colon & Yes/Caecum & Yes/Small colon \\
\hline Diarrhoea onset after surgery & 3 days & 1 day & 1 day & 2 days \\
\hline Fever & Yes $\left(39,9^{\circ} \mathrm{C}\right)$ & Yes $\left(40,8^{\circ} \mathrm{C}\right)$ & Yes $\left(39,7^{\circ} \mathrm{C}\right)$ & Yes $\left(39,4^{\circ} \mathrm{C}\right)$ \\
\hline Heart rate & 48 beats/min & 60 beats/min & 36 beats/min & 88 beats/min \\
\hline Respiratory rate & 16 breaths/min & 40 breaths $/ \mathrm{min}$ & 28 breaths $/ \mathrm{min}$ & 24 breaths/min \\
\hline Oral mucous membrane & Rose / Slightly dry & Congest / Dry & Congest / Dry & Congest / Slightly dry \\
\hline Capillary refill time & 3 seconds & 4 seconds & 3 seconds & 4 seconds \\
\hline Intestinal auscultation & Normal & Normal & Hypermotility & Normal \\
\hline Packed cell volume & $43 \%$ & $39 \%$ & $47 \%$ & $40 \%$ \\
\hline Leukocytes & $4300 / \mu \mathrm{L}$ & $2900 / \mu \mathrm{L}$ & $5100 / \mu \mathrm{L}$ & $7400 / \mu \mathrm{L}$ \\
\hline Total plasma protein & $5.5 \mathrm{~g} / \mathrm{dL}$ & $3.4 \mathrm{~g} / \mathrm{dL}$ & $7.0 \mathrm{~g} / \mathrm{dL}$ & $6.3 \mathrm{~g} / \mathrm{dL}$ \\
\hline Plasma fibrinogen & $700 \mathrm{mg} / \mathrm{dL}$ & $300 \mathrm{mg} / \mathrm{dL}$ & $700 \mathrm{mg} / \mathrm{dL}$ & $400 \mathrm{mg} / \mathrm{dL}$ \\
\hline FMT after diarrhoea onset & 5 days & Immediately & Immediately & Immediately \\
\hline $\begin{array}{l}\text { Time to control diarrhoea and } \\
\text { fever }\end{array}$ & Within 24 hours & Within 24 hours & Within 24 hours & Within 24 hours \\
\hline Time to restore normal defecation & 8 days & 2 days & 1 day & 1 day \\
\hline Colitis resolution after 1 FMT & Total & Total & Total & Total \\
\hline Complications following colitis & $\begin{array}{l}\text { Laminitis and jugular } \\
\text { thrombophlebitis }\end{array}$ & Peritonitis and cachexia & None & Suture line infection \\
\hline Short term survival (to discharge) & Alive & Dead & Alive & Alive \\
\hline Long term follow-up & No diarrhoea history & Dead & No diarrhoea history & No diarrhoea history \\
\hline
\end{tabular}


acute colitis usually occurs in horses from 2 to 10 years old. Characteristic clinical signs such as diarrhoea and fever were observed in all cases, as described by Feary \& Hassel (2006), and disappeared with a single FMT. Three of the 4 horses showed leukopenia that could initially be associated with acute colitis (Mair \& Smith 2005). However, clinical findings are nonspecific, and low leukocyte counts may also result from primary intestinal lesions and surgical manipulation, compromising diagnosis.

According to Uzal \& Diab (2015), owing to the large range of aetiologies involving different pathogens, the causes of a significant number of severe inflammatory intestinal lesions remain undetermined. Despite the indeterminate diagnosis, FMT has proven to be a simple nonspecific treatment for acute colitis associated with supportive care, yielding a rapid cure rate of $100 \%$ of the reported cases. The FMT showed two major advantages compared with traditional supportive care alone: the first advantage was the rapid recovery time, with diarrhoea and fever controlled within 24 hours after FMT, as opposed to the long process of supportive care in which horses gradually recover over a 7- to 14-day period (McConnico 2009); the second advantage is that FMT is very low in cost compared with long treatment using antimicrobials and a large volume of parenteral fluids. Probiotics are also indicated for acute colitis of horses, aiming to balance the intestinal microbiota (Julliand \& Zeyner 2009). According to Weese (2002) probiotics must contain microorganisms robust enough to withstand processing and storage, but quality control for commercial veterinary products is poor. Therefore, FMT has the advantage of being natural and preserving alive microorganisms that compose the intestinal microbiota of a horse.

Considering the procedure, oral antacids such as omeprazole are indicated before FMT administration (Feary \& Hassel 2006), and all horses had already taken ranitidine and omeprazole for surgery. This recommendation aims to minimize microbial death from the acid gastric environment, the same objective for which our technique proposes the addition of sodium bicarbonate to the diluted faeces before administration. The principle behind the use of bicarbonate in FMT is the physiological secretion of large amounts of bicarbonate along digestive tract to buffer hydrochloric acid produced in the stomach (Herdt \& Sayegh 2013). Since FMT contributed as an additional treatment to control acute colitis, one can conclude that the gastric acidity was buffered and microorganisms passed alive through the acid environments. However, the effectiveness of sodium bicarbonate in FMT should be thoroughly investigated.

Regarding complications, horses presenting caecal impaction (1 and 3) and small colon faecaliths (4) were referred to surgery after a long period of medical treatment (1 to 6 days), supported by administration of fluids, analgesics and sedatives. The delay before treatment of intestinal obstruction was strongly associated with complications observed after surgery, and the first complication observed was acute colitis. According to Hackett \& Hassel (2009), horses treated surgically for large intestine obstructions may be at increased risk for developing colitis postoperatively.

Although colitis is primarily classified as an inflammatory disease (Feary \& Hassel 2006), the intestinal intraluminal environment is full of microorganisms and always produces an infectious condition. The pathogenic microbes first multiply and then die, releasing endotoxin. The main consequence is the development of sepsis in different degrees, which features the activation of proinflammatory mediators (Roy 2004). In the present report, horse 1 showed laminitis and jugular thrombophlebitis, reported to be common secondary complications of acute colitis (Dolente et al. 2002). For this case, FMT was performed late (5 days) after the onset of diarrhoea and fever, and this decision was based on the statement of Feary \& Hassel (2006) that "all antimicrobials should be discontinued" before FMT in horses. This precaution is usually taken to prevent the death of the transplanted microbiota. Thus, due to the high risk of infection following laparotomy, the decision was made to continue antimicrobial therapy as scheduled and resort to traditional supportive care to normalize fluid, electrolyte, and colloid deficits (Feary \& Hassel 2006, Hackett \& Hassel 2009). During this period of 5 days before FMT, colitis persisted, allowing sepsis to last, which predisposed the horse to laminitis because hoof matrix metalloproteinase enzymes were activated and destroyed lamellar tissues (Pollitt 2004); in addition, sepsis predisposed the horse to jugular thrombophlebitis stimulating a state of hypercoagulability, associated with vessel wall trauma from the catheter implanted in the jugular vein (Dolente et al. 2005). The other 3 horses, which received FMT immediately after diarrhoea and fever onset without discontinuing antimicrobials, showed prompt resolution of acute colitis, and sepsis did not progress. In humans, clinical studies showed that FMT normalized the intestinal flora to such an extent that antimicrobials became effective (Aas et al. 2003, Brandt \& Reddy 2011, Brandt 2012). The same phenomenon may have occurred with the horses, and since acute colitis was controlled for the present cases, we do not indicate stopping the antimicrobials prescribed for colic surgery prophylaxis to perform FMT.

Horse 2 developed peritonitis and cachexia and died 45 days after diarrhoea and fever resolution. This horse had large colon volvulus, and despite had survived surgery and colitis, it developed life-threatening complications. Resection was not carried out because the site of torsion was at the base of the large colon, and peritonitis developed in response to the continued intestine devitalisation, as described by Rakestraw \& Hardy (2012). The suture line infection presented by horse 4 was superficial, healed with topical treatment and could not be associated with acute colitis.

Other forms of intestinal microbiota transplantation include infusing manure from healthy horses into the rectum of the sick animals (Brandt 2012) and using a nasogastric tube to administer caecal contents obtained immediately post mortem from a healthy donor (Feary \& Hassel 2006, Mullen et al. 2016). However, faeces introduced into the rectum do not reach the caecum and large colon to restore its microbiota. Furthermore, it is impossible to have fresh caecal contents always available for routine use; thus, these two techniques are at a disadvantage compared with FMT as proposed in the present study. The main risk of FMT is transmission of infectious disease, which can be avoided by performing prior laboratory testing (Feary \& Hassel 2006). In our experience, when a healthy horse was chosen as a donor, no side effects were observed.

Faecal microbiota transplantation provides millions of living organisms, and further research is needed to determine precisely which of the organisms or products in FMT is 
responsible for controlling colitis. Once the appropriate organisms can be identified to treat specific diseases, FMT will no longer need to be performed, and living organisms will replace antimicrobials for the treatment of GIT infectious disease (Brandt 2012). This preliminary investigation of 4 horses with acute colitis following colic surgery suggests that FMT is sufficient to restore normal manure habits and eliminate clinical signs. Although exchange of genetic material amongst bacteria in the equine GIT must be considered as a possible side effect (Julliand \& Zeyner 2009, Dicks et al. 2014), FMT avoids drug resistance in comparison with the traditional colitis treatment, which includes antimicrobial therapy. Furthermore, the rapid control of intestinal lesions by FMT decreases the duration of colitis, preventing sepsis progression and its secondary complications and thereby lowering treatment cost. Although FMT was successful in the present study, the use of this technique should be evaluated with caution and consideration; further investigation is needed regarding the optimal preparation, safety, mode of action and real effects of homologous FMT for the prevention and treatment of acute colitis. By reintroducing a new diversity of bacteria, FMT is showing a great promise as an inexpensive, safe and highly efficient alternative to antimicrobials in the fight against infectious gastrointestinal diseases in horses.

Conflict of interest statement.- The authors declare that they have no conflict of interest.

Ackowledgements.- The authors acknowledge referring veterinarians and veterinary hospital clinical staff for their invaluable contribution to the success of these cases.

\section{REFERENCES}

Aas J., Gessert C.E. \& Bakken J.S. 2003. Recurrent Clostridium difficile colitis: case series involving 18 patients treated with donor stool administered via a nasogastric tube. Clin. Infect. Dis. 36(5):580-585. <http://dx.doi. org/10.1086/367657><PMid:12594638>

Brandt L.J. \& Reddy S.S. 2011. Fecal microbiota transplantation for recurrent Clostridium difficile infection. J. Clin. Gastroenterol. 45(Suppl.):S159-S167. <http://dx.doi.org/10.1097/MCG.0b013e318222e603><PMid:21992957>

Brandt L.J. 2012. Fecal transplantation for the treatment of Clostridium difficile infection. Gastroenterol. Hepatol. 8(3):191-194.<PMid:22675283>

Dendukuri N., Costa V., McGregor M. \& Brophy J.M. 2005. Probiotic therapy for the prevention and treatment of Clostridium difficile-associated diarrhea: a systematic review. Can. Med. Assoc. J. 173(2):167-170. <http://dx.doi. org/10.1503/cmaj.050350><PMid:16027434>

DePeters E.J. \& George L.W. 2014. Rumen transfaunation. Immunol. Lett. 162(Pt 2A):69-76. <http://dx.doi.org/10.1016/j.imlet.2014.05.009> $<$ PMid:25262872>

Dicks L.M.T., Botha M., Dicks E. \& Botes M. 2014. The equine gastro-intestinal tract: an overview of the microbiota, disease and treatment. Livest. Sci. 160:69-81. <http://dx.doi.org/10.1016/j.livsci.2013.11.025>

Dolente B.A., Wilkins P.A. \& Boston R.C. 2002. Clinicopathologic evidence of disseminated intravascular coagulation in horses with acute colitis. J. Am. Vet. Med. Assoc. 220(7):1034-1038. <http://dx.doi.org/10.2460/ javma.2002.220.1034><PMid:12420783>

Dolente B.A., Beech J., Lindborg S. \& Smith G. 2005. Evaluation of risk factors for development of catheter-associated jugular thrombophlebitis in horses: 50 cases (1993-1998). J. Am. Vet. Med. Assoc. 227(7):1134-1141.<http:// dx.doi.org/10.2460/javma.2005.227.1134><PMid:16220676>

DuToit N., Burden F.A., Getachew M. \& Trawford A.F. 2010. Idiopathic typhlocolitis in 40 aged donkeys. Equine Vet. Educ. 22(2):53-57. <http:// dx.doi.org/10.2746/095777309X480894>
Feary D.J. \& Hassel D.M. 2006. Enteritis and colitis in horses. Vet. Clin. N. Am., Equine Vet. Pract. 22(2):437-479, ix. <http://dx.doi.org/10.1016/j. cveq.2006.03.008><PMid:16882483>

Gibson G.R. \& Fuller R. 2000. Aspects of in vitro and in vivo research approaches directed toward identifying probiotics and prebiotics for human use. J. Nutr. 130(Suppl.2):391S-395S. <http://dx.doi.org/10.1093/ jn/130.2.391S > <PMid:10721913>

Hackett E.S. \& Hassel D.M. 2009. Colic: nonsurgical complications. Vet. Clin. N. Am., Equine Vet. Pract. 24(3):535-555. <http://dx.doi.org/10.1016/j. cveq.2008.09.001>

Herdt T.H. \& Sayegh A.I. 2013. Physiology of the gastrointestinal tract, p.263358. In: Klein B.G. (Ed.), Cunningham's Textbook of Veterinary Physiology. 5th ed. Elsevier Saunders, St Louis.

Julliand V. \& Zeyner A. 2009. The pros and cons of probiotics, p.83-86. In: Robinson N.E. \& Sprayberry K.A. (Eds), Current Therapy in Equine Medicine. 6th ed. Saunders, St Louis.

Magdesian K.G. 2003. Nutrition for critical gastrointestinal illness: feeding horses with diarrhea or colic. Vet. Clin. N. Am., Equine Vet. Pract. 19(3):617644. <http://dx.doi.org/10.1016/j.cveq.2003.08.011><PMid:14740760>

Mair T.S. \& Smith L.J. 2005. Survival and complication rates in 300 horses undergoing surgical treatment of colic. Part 2: short-term complications. Equine Vet. J. 37(4):303-309. <http://dx.doi.org/10.2746/0425164054529364> <PMid:16028617>

McConnico R.S. 2009. Acute equine colitis, p.418-423. In: Robinson N.E. \& Sprayberry K.A. (Eds), Current Therapy in Equine Medicine. 6th ed. Saunders, St Louis.

Metchnikoff E. 1908. The prolongation of life: optimistic studies. G.P. Putnam's Sons, New York. 380p.

Mullen K.R., Yasuda K., Divers T.J. \& Weese J.S. 2016. Equine faecal microbiota transplant: current knowledge, proposed guidelines and future directions. Equine Vet. Educ. <http://dx.doi.org/10.1111/eve.12559>

Ott S.J., Waetzig G.H., Rehman A., Moltzau-Anderson J., Bharti R., Grasis J.A., Cassidy L., Tholey A., Fickenscher H., Seegert D., Rosenstiel P. \& Schreiber S. 2017. Efficacy of sterile fecal filtrate transfer for treating patients with Clostridium difficile infection. Gastroenterology 152(4):799-811e7.<http:// dx.doi.org/10.1053/j.gastro.2016.11.010><PMid:27866880>

Pollitt C.C. 2004. Equine laminitis. Clin. Tech. Equine Pract. 3(1):34-44. <http://dx.doi.org/10.1053/j.ctep.2004.07.003>

Rakestraw P.C. \& Hardy J. 2012. Large intestine, p.454-494. In: Auer J.A. \& Stick J.A. (Eds), Equine Surgery. 4th ed. Elsevier Saunders, St Louis. <http:// dx.doi.org/10.1016/B978-1-4377-0867-7.00037-5>.

Roy M.F. 2004. Sepsis in adults and foals. Vet. Clin. N. Am., Equine Vet. Pract. 20(1):41-61. <http://dx.doi.org/10.1016/j.cveq.2003.12.005> <PMid:15062458>

Saarela M., Mogensen G., Fondén R., Mättö J. \& Mattila-Sandholm T. 2000 Probiotic bacteria: safety, functional and technological properties. J. Biotechnol. 84(3):197-215. <http://dx.doi.org/10.1016/S0168-1656(00)00375-8> $<$ PMid:11164262>

Southwood L.L. 2006. Acute abdomen. Clin. Tech. Equine Pract. 5(2):112126. <http://dx.doi.org/10.1053/j.ctep.2006.03.005>

Uzal F.A. \& Diab S.S. 2015. Gastritis, enteritis, and colitis in horses. Vet. Clin. N. Am., Equine Vet. Pract. 31(2):337-358. <http://dx.doi.org/10.1016/j. cveq.2015.04.006><PMid:26048413>

Weese J.S. 2002. Microbiologic evaluation of commercial probiotics. J. Am. Vet. Med. Assoc. 220(6):794-797. <http://dx.doi.org/10.2460/ javma.2002.220.794><PMid:11918274>

Weese J.S., Anderson M.E.C., Lowe A., Penno R., Costa T.M., Button L. \& Goth K.C. 2004. Screening of the equine intestinal microflora for potential probiotic organisms. Equine Vet. J. 36(4):351-355. <http://dx.doi. org/10.2746/0425164044890616> <PMid:15163044> 